\title{
KONSEP ASAS PEMBENTUKAN INDIKATOR BANDAR SEJAHTERA MENURUT PERSPEKTIF ISLAM
}

\author{
Norizam Lagiman ${ }^{\mathrm{a}}$, Ibrahim Ngah ${ }^{\mathrm{b}^{*}}$, Ismail Mustaric ${ }^{\mathrm{c}}$, Siti Norashikin Bashirun ${ }^{\mathrm{d}}$, \\ ${ }^{a}$ Fakulti Alam Bina, Universiti Teknologi Malaysia, Johor Bahru, Johor \\ ${ }^{b}$ Pusat Perancangan dan Pembangunan Inovatif (CIPD), Universiti Teknologi Malaysia, Johor \\ ${ }^{c}$ Fakulti Tamadun Islam, Universiti Teknologi Malaysia, Johor Bahru, Johor \\ ${ }^{d}$ Fakulti Pengurusan Perniagaan, Universiti Teknologi Mara, (UiTM) Kampus Bandaraya Melaka \\ *Corresponding author:b-ibrhim@utm.my
}

\section{Article history}

Received: 2015-01-01

Received in revised form: 2015-05-16

Accepted : 2015-03-12

\begin{abstract}
City is the central development of the human civilization. The emergence of Islam as a greatest religion and most glorious began from the city. The aims of the study are to identify the concepts, principles and characteristics of wellbeing Islamic city and to establish indicators based on Islamic scholars opinion. It is also to measure the level of wellbeing city based on the indicators produced and to identify the implications of planning policy and urban community development. Result shows that, economic, faith and physical scored highest for developing cultural-economic indicators among the population endowment scored $\min$ 4.91. Faith-resident reading al-Quran as a daily practice indicator scored 4.90 and physical indicators of the existence of a clean environment scored min 4.89. Overall, the study found that the wellbeing of a city influenced by spiritual compared with physical factors.
\end{abstract}

Keywords: Indicator, City, Development, Well Being, Urban Planning

\begin{abstract}
Abstrak
Bandar adalah pusat kepada perkembangan tamadun manusia. Kemunculan Islam sebagai agama teragung dan mulia adalah bertitik mula dari bandar. Tujuan kajian ini dilakukan adalah untuk mengenalpasti konsep, prinsip dan ciri bandar sejahtera berteraskan Islam dan membentuk indikator bandar sejahtera berasaskan pandangan cendekiawan Islam seterusnya mengukur tahap kesejahteraan sesebuah bandar menerusi set indikator kesejahteraan bandar yang dihasilkan dan mengenalpasti implikasi kajian terhadap dasar perancangan dan pembangunan masyarakat bandar. Kaedah kajian menggunakan rekabentuk kajian tinjauan dengan teknik pengumpulan data melalui soal selidik. Hasil kajian mendapati, faktor ekonomi, akidah dan fizikal mendapat skor tertinggi iaitu bagi indikator ekonomi iaitu berkembang budaya waqaf dikalangan penduduk mendapat skor min 4.91. Bagi indikator akidah iaitu penduduk membaca al-Quran sebagai amalan harian mendapat skor 4.90 dan indikator fizikal iaitu kewujudan persekitaran bersih mendapat skor min 4.89. Secara keseluruhannya, kajian mendapati bahawa kesejahteraan sesebuah bandar dipengaruhi oleh faktor spiritual jika dibandingkan dengan faktor fizikal.
\end{abstract}

Kata kunci: Indikator, Bandar, Perbandaran, Kesejahteraan, Perancangan Bandar 


\subsection{PENGENALAN}

Islam adalah agama yang bersumberkan al-Quran dan al-Sunnah sebagai asas panduan dalam membangunkan kehidupan. Kemunculan Islam sebagai agama teragung dan mulia adalah bertitik mula dari bandar sebagaimana kewujudan bandar pertama Islam di Madinah. Kehidupan bandar telah mencorakkan tamadun Islam sehingga berjaya melahirkan pelbagai institusi berbentuk sosial, politik, ekonomi dan budaya yang membentuk masyarakat madani, mengatasi masyarakat Barat pada ketika itu yang masih berada dalam Zaman Kegelapan. Dengan kewibawaan umat Islam, mereka membina bandar dan membangunkan masyarakatnya menjadi maju, makmur, sejahtera, aman, adil dan berakhlak mulia sehingga menjadi masyarakat yang bertamadun. Pada asasnya, Islam telah berjaya melahirkan bandar yang sejahtera sebagaimana zaman kegemilangan umat Islam terdahulu.

Pada masa kini, persoalan tentang kesejahteraan hidup di bandar dan indikator kesejahteraan secara umumnya semakin menjadi tumpuan. Kebanyakan kajian awal indikator telah dilakukan oleh negara maju di Barat (Paola Jiron \& Giulieta Fadda,1999). Daripada kajian-kajian tersebut, mereka berpendapat bahawa indikator merupakan ukuran penting dalam menilai status kesejahteraan hidup di kawasan bandar. Kata indikator itu sendiri telah memberi makna menunjukkan amaran, panduan, isyarat atau kesan. Istilah ini pada umumnya berasal dari perkataan Latin iaitu indicare yang membawa maksud mendedahkan atau menunjuk arah, memberitahu secara umum atau menilai, malah indikator merupakan alat pengukuran yang boleh digunakan dengan berkesan untuk membolehkan pihak berkepentingan menilai pencapaian komuniti tertentu (Ahmad Hezri, 2002). Perkataan 'indikator' juga memberi maksud variable yang membantu kita dalam mengukur perubahan-perubahan yang terjadi baik secara langsung atau pun tidak langsung (WHO, 1981). Variable-variable memberi petunjuk kepada kita tentang suatu keadaan tertentu, sehingga boleh digunakan untuk mengukur perubahan (Green, 1992). Indikator juga sesuatu yang boleh membantu untuk menjelaskan kedudukan arah dan sejauh mana matlamat yang ditetapkan itu akan tercapai (Hart,1999).

Pembangunan indikator untuk mengukur pencapaian perancangan bandar mengikut konsep pembangunan lestari telah banyak dilakukan. Contoh terkini, rangkaian bandar lestari antarabangsa (Sustainable Cities International) pada tahun 2012 telah menjalankan kajian perbandingan indikator kelestarian bagi 12 bandar terpilih di Afrika, Amerika, Asia, Australia, Eropah dan Timur tengah. Dalam kajian ini, indikator kelestarian di senaraikan dan dibandingkan bagi setiap bandar tersebut dan indikator yang lazim diguna pakai oleh lebih dari tiga buah bandar telah dikenal pasti, dan dijadikan sebagai panduan (Jadual 1).

Berasaskan tinjauan terhadap konsep indikator, contoh indikator bandar lestari dapat disimpulkan bahawa indikator pembangunan sedia ada di peringkat bandar adalah lebih berbentuk pembangunan material yang merangkumi dimensi sosial, ekonomi dan fizikal. Ia tidak mengambil kira dimensi spiritual (hubungan manusia dengan Allah SWT) yang sangat penting untuk mencapai kesejahteraan secara menyeluruh. Pendekatan menyeluruh ini hanya dapat diperoleh daripada sumber rujukan Islam, iaitu alQuran dan al-Sunnah.

\subsection{KONSEP DAN TEORI PERBANDARAN ISLAM}

Sesebuah tamadun lahir dari kewujudan sebuah bandar (Ahmad Zaki Abdul Latif,1997). Tahap kehidupan tertinggi yang dicapai oleh manusia digelar tamadun. Perubahan sistem kehidupan yang lebih kompleks adalah merupakan perubahan sosial (Ting Chew Peh, 1993). Fungsi sesebuah bandar yang semakin dinamik dan kompleks masa kini sebenarnya dirujuk kepada model perbandaran Barat meskipun model perbandaran dari Timur telah lama wujud. Dalam Islam, tujuan perbandaran adalah untuk menjaga kemaslahatan umumiah (kepentingan umum), manakala agama Islam dijadikan ramuan asas dalam pembentukan masyarakat kota yang bertamadun (Ahmad Zaki Abdul Latif,1997). 
Norizam Lagiman et al. / UMRAN - International Journal of Islamic and Civilizational Studies. vol.2. no.3 (2015) 10-24

\begin{tabular}{|c|c|c|}
\hline Sektor & Indikator Umum & Indikator Khusus \\
\hline \multirow[t]{7}{*}{ Ekonomi } & \multirow[t]{3}{*}{ Kadar pengangguran/pekerjaan } & Kadar pengganguran/kadar underemployment \\
\hline & & Peratus pekerjaan hijau \\
\hline & & Purata tahun pendidikan profesional bagi tenaga kerja \\
\hline & \multirow[t]{4}{*}{ Pertumbuhan ekonomi } & Kadar pertumbuhan tahunan GDP \\
\hline & & Kadar pertumbuhan tahunan GNP \\
\hline & & Kadar eksport bersih \\
\hline & & Pelaburan asing langsung \\
\hline \multirow{12}{*}{$\begin{array}{l}\text { Alam } \\
\text { sekitar }\end{array}$} & \multirow[t]{2}{*}{ Ruang hijau } & Peratus kawasan hijau kepada jumlah kawasan \\
\hline & & Peratus pokok kepada luas kawasan/penduduk \\
\hline & \multirow{2}{*}{$\begin{array}{l}\text { Pengurangan gas rumah hijau } \\
\text { /kecekapan tenaga }\end{array}$} & Jumlah GHG dihasilkan per bandar/ per kapita \\
\hline & & $\begin{array}{l}\text { Peratus jumlah tenaga digunakan bersumberkan tenaga } \\
\text { diperbaharui }\end{array}$ \\
\hline & \multirow{5}{*}{$\begin{array}{l}\text { Mobiliti } \\
\text { Kualiti air /kedapatan }\end{array}$} & Modal split pengangkutan \\
\hline & & Purata commute time dan kos \\
\hline & & Jumlah air yang ada \\
\hline & & Indeks/skor kualiti air \\
\hline & & $\begin{array}{l}\text { Nisbah penduduk akses kepada air yang diminum selamat } \\
\& \text { mencukupi }\end{array}$ \\
\hline & Kualiti udara & Tahap bahan mendapan (PM10-mg/m3) \\
\hline & \multirow[t]{2}{*}{ Air diguna semula / kitar semula } & Kadar kitar semula \\
\hline & & Isipadu sisa pepejal dijanakan \\
\hline \multirow[t]{12}{*}{ Sosial } & \multirow[t]{3}{*}{ Kejiranan lengkap/padat } & Akses kepada perkhidmatan tempatan pada jarak singkat \\
\hline & & Kadar jenayah \\
\hline & & Pengukuran agihan pendapatan dan ketidakseimbangan \\
\hline & \multirow[t]{2}{*}{ Perumahan } & Peratus perumahan sosial/mampu milik/ keutamaan \\
\hline & & Pecahan sektor perumahan mengikut jenis \\
\hline & \multirow[t]{2}{*}{ Kualiti ruang awam } & Peratus laluan jalan berkeadaan baik \\
\hline & & Peratus ruang hijau kepada luas kawasan bandar \\
\hline & \multirow[t]{2}{*}{ Pendidikan } & Bilangan sekolah dengan program pendidikan alam sekitar \\
\hline & & Kadar celik huruf orang dewasa \\
\hline & Kebersihan & $\begin{array}{l}\text { Peratus penduduk akses kepada infrastruktur } \\
\text { pembentungan }\end{array}$ \\
\hline & \multirow[t]{2}{*}{ Kesihatan } & Kadar kematian / jangka hayat \\
\hline & & $\begin{array}{l}\text { Peratus penduduk akses kepada perkhidmatan penjagaan } \\
\text { kesihatan }\end{array}$ \\
\hline
\end{tabular}

Sumber: SCI (2012)

Perbandaran dirujuk sebagai ketamadunan (umran, hadarah, madaniyah, tamadun) oleh masyarakat Arab yang menekankan kepada masyarakat yang maju dan terbangun nilai keinsanannya (Mohammad Tajuddin Mohamad Rasdi \& Rosdan Abdul Manan, 2001). Konsep perbandaran dalam dua lingkungan ini ternyata berbeza serta memberi gambaran struktur sosial sesebuah masyarakat sama ada telah mencapai suatu sistem kehidupan yang lebih kompleks, seperti yang disebut oleh Durkheim sebagai kesepaduan organik ataupun tidak (dlm. Ting Chew Peh, 1993). Justeru itu, konsep perbandaran seharusnya dilihat dalam konteks yang lebih kompleks iaitu seluruh struktur pembentukan ketamadunan sebagaimana 
digambarkan dalam kajian-kajian perbandaran Islam yang ditulis dalam tulisan arab klasik sehingga kepada penulis-penulis Islam moden (Ahmad Zaki Abdul Latiff 1997; Mohammad Tajuddin Mohamad Rasdi \& Rosdan Abdul Manan, 2001).

Perbandaran Islam mempunyai beberapa konsep yang menyentuh aspek fizikal dan spiritual yang dikenalpasti sejak zaman Rasulullah S.A.W. dan Zaman Khulafa'al-Rasyidin. Pada zaman terkemudian pertembungan budaya antara Rom dan Parsi pada Zaman Umayyah dan Abasiyyah menyebabkan berlakunya perubahan dalam konsep perbandaran Islam dari aspek perkembangan fizikal, sosio budaya dan institusi. Daripada kajian bandar Islam terdahulu (Ahmad Zaki, 1997), perkara yang jelas membezakan sifat bandar Islam ialah dimensi bukan fizikal seperti aqidah penduduknya, pelaksanaan syariat Islam, pembangunan institusi dakwah dan aktiviti-aktiviti penduduknya yang menzahirkan sistem kehidupan Islam.

Perkara penting dalam sistem hidup Islam ialah untuk melengkapkan diri manusia supaya dapat mengurus diri agar mampu menjadi insan yang bertakwa, beriman, beradab dan beribadah iaitu menjaga hubungan dengan Allah SWT. Islam juga mendidik manusia supaya mampu mengurus sistem yang ada seperti ekonomi, politik, sosial dan budaya yang dinamakan ilmu kifayah iaitu untuk menjaga hubungan manusia dengan manusia yang lain seperti mana yang diperintah dalam al-Quran dan al-Sunnah. Islam dalam membentuk baldatun thoibah (bandar yang baik) sebagaimana maksud firman Allah dalam surah Saba' ayat 15; “.... bandar yang baik dan mendapat keampunan Allah,” tidak menolak kaedah inovatif dan kreatif seperti menjalankan penyelidikan, asalkan tidak bertentangan dengan ajaran Islam.

Dari sudut falsafah dan epistemologi, terdapat perbezaan yang jelas di antara bandar sejahtera dan bandar tidak sejahtera. Perbezaan pertama ialah bandar sejahtera mempunyai sumber epistemologi ilmu yang jelas dan sesuai sepanjang masa, iaitu sumber daripada al-Quran dan al-Sunnah. Sedangkan bandar tidak sejahtera lebih bersandarkan kepada epistemologi akal dan rasionaliti yang berubah mengikut peredaran masa. Kedua, bandar sejahtera mempunyai ruang untuk aplikasi ilmu dan mesra persekitaran ilmu, sedangkan bandar tidak sejahtera memperdagangkan ilmu dan hanya yang berkemampuan sahaja mendapat kelebihan pengetahuan. Mereka yang tidak berkemampuan akan terus ketinggalan. Bandar sejahtera dari perspektif Islam tidak dapat dipisahkan dari sistem hidup Islam itu sendiri yang bersumber al-Quran dan al-Sunnah. Kesejateraan dalam Islam hanya tercapai apabila Islam diterima pakai dan dihayati secara keseluruhan dalam setiap peringkat dan dimensi kehidupan merangkumi peringkat individu, keluarga, masyarakat dan negara dan dimensi akidah, sosio-budaya, ekonomi, institusi pentadbiran dan fizikal. Perancangan bandar sejahtera perlu dilihat dalam konteks kesepaduan sistem hidup Islam yang diterjemahkan dalam aktiviti kehidupan seharian masyarakat (sistem aktiviti) dan dimenifestasi ke dalam ruang dan rekabentuk fizikal (sistem ruang) (Rajah 1).

Dalam sistem hidup Islam yang dipanggil syariat Islam, matlamat utamanya adalah untuk menjamin kesejahteraan hidup umat Islam di dunia dan di akhirat. Prinsip utama yang menjadi asas panduan bagi mencapai konsep al-falah (kejayaan hidup didunia dan akhirat) ialah Maqasid Syariah. Daripada sistem hidup Islam ini, lahirlah aktiviti dan perlakuan manusia di bandar seperti aktiviti pendidikan, ibadah, perniagaan, kebajikan dan lain-lain. Pola ruang dalam bandar merupakan manifestasi daripada sistem dan aktiviti yang mempunyai hubung kait dengan sistem hidup dan akidah. Kesepaduan keseluruhan akidah, aktiviti dan pola ruang yang berteraskan al-Quran dan al-Sunnah sahaja yang akan melahirkan bandar yang sejahtera. 


\section{AQIDAH ISLAM}

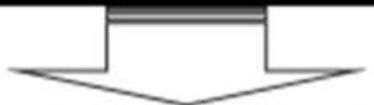

\section{SISTEM KEHIDUPAN ISLAM}

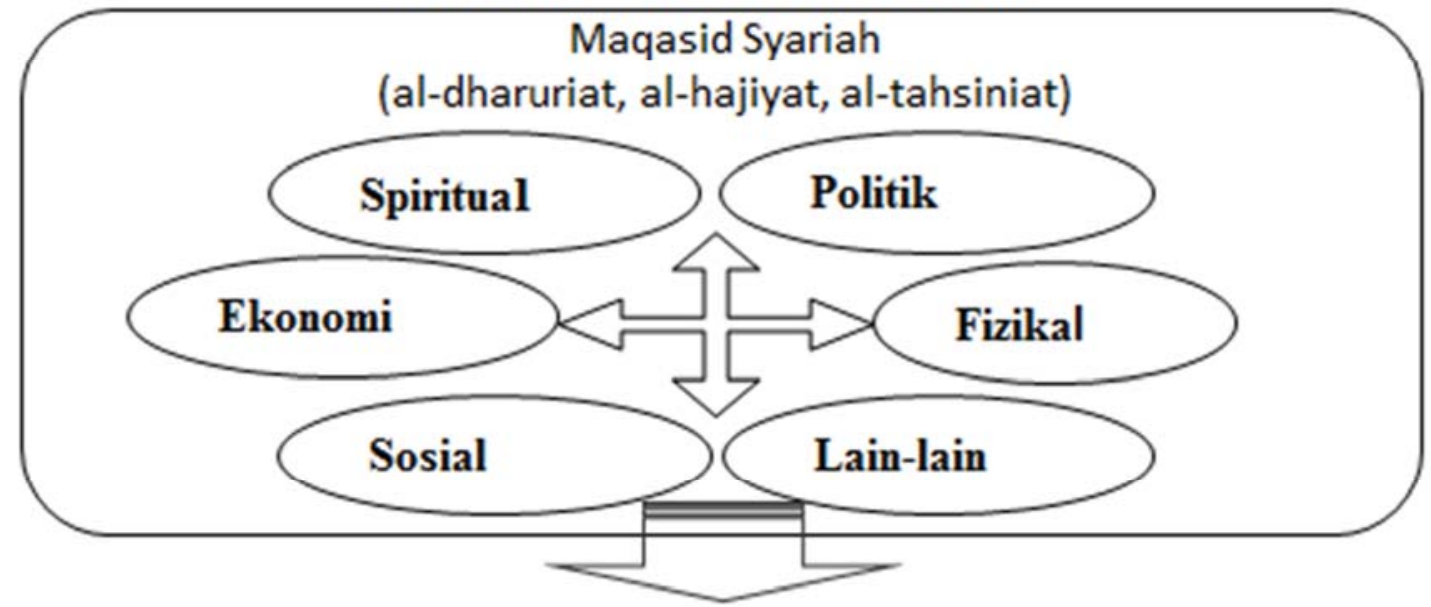

\section{SISTEM AKTIVITI}

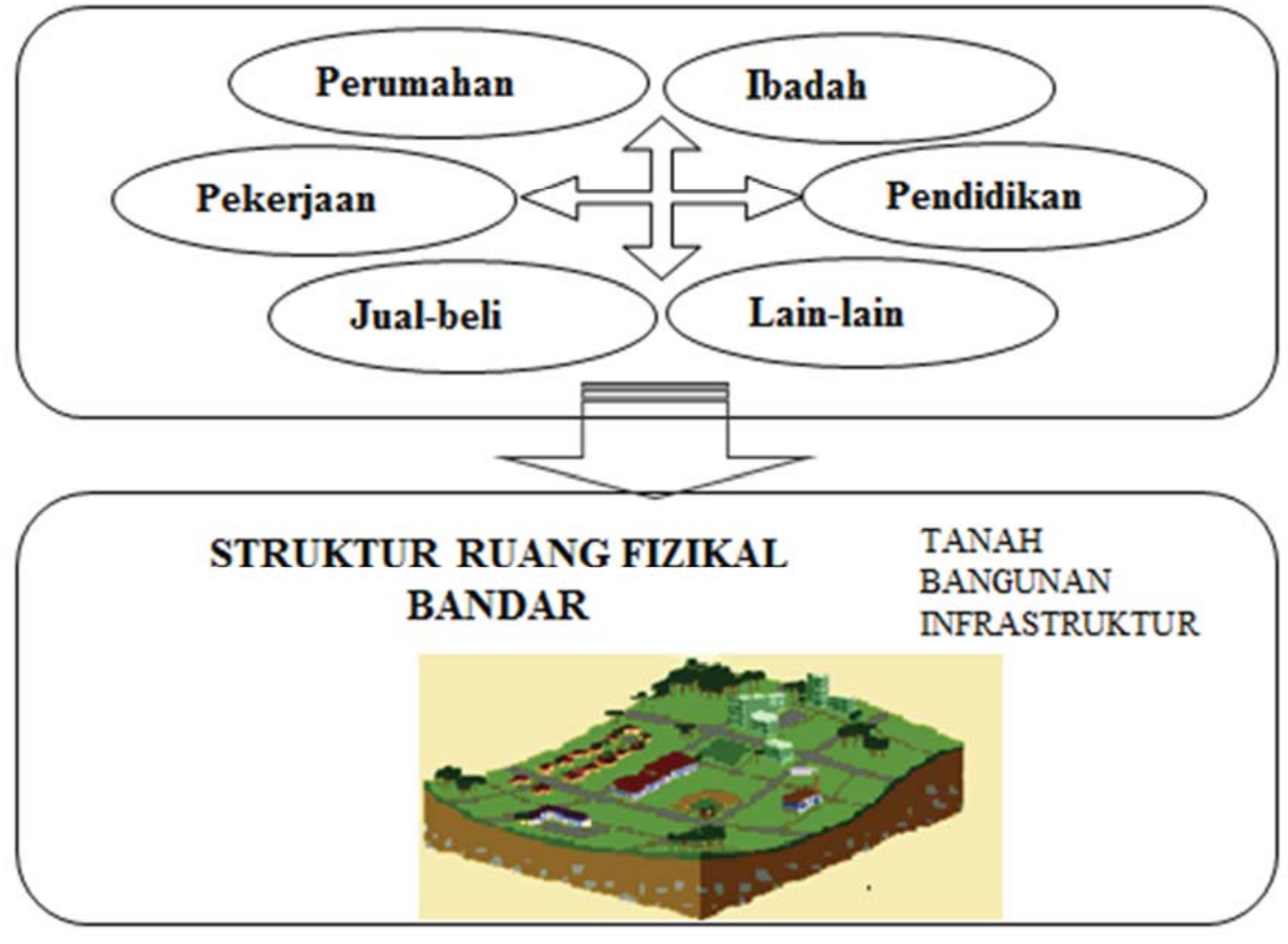




\subsection{KAEDAH KAJIAN}

Kajian terhadap indikator kesejahteraan bandar ini dimulakan dengan membuat tinjauan awal daripada al-Quran dan al-Sunnah serta kajian-kajian lepas, maka sebanyak 63 indikator awal telah dihasilkan. Indikator-indikator ini telah dibengkelkan bersama empat orang pakar bidang di Universiti Teknologi Malaysia (UTM). Hasil perbincangan bersama pakar bidang, maka dibuat penambahan 9 indikator dan menjadikan 72 indikator. Setelah penilaian indikator dilakukan berdasarkan persetujuan pakar, maka telah dilaksanakan kajian rintis untuk mengesahkan indikator yang telah dihasilkan. Borang soal selidik yang dibangunkan oleh penyelidik telah diuji kebolehpercayaan dan kesahannya dengan memperolehi nilai Cronbach Alpha 0.91. Nilai Cronbach Alpha yang diperoleh adalah tinggi iaitu melebihi $>0.9$. Pengesahan kepentingan indikator tersebut dilakukan dalam bentuk borang soal selidik kepada responden yang terdiri daripada cendekiawan Islam dan diukur dengan menggunakan skala likert. Responden juga diberi peluang untuk memberikan pendapat dalam borang soal selidik untuk menilai kepentingan indikator dan menambah indikator yang bersesuaian. Seramai 150 orang responden yang mewakili tiga kumpulan responden iaitu agamawan, ahli akademik dan perancang bandar telah dilibatkan dalam kajian Delphi ${ }^{1}$ yang dijalankan. Pada Delphi pusingan pertama hanya 109 orang yang menjawab soal selidik yang diberikan. Namun begitu, selepas berakhirnya dua pusingan soal selidik, hanya 70 orang daripada mereka yang melengkapkan kedua-dua pusingan kajian Delphi yang dijalankan. Oleh yang demikian, perbincangan dalam bahagian ini hanya melibatkan latarbelakang 109 orang responden sahaja yang dibincangkan. Daripada 109 orang responden, 38 orang responden dari kumpulan 1. Jadual 2 menunjukkan latarbelakang 38 orang responden berkenaan. Berdasarkan jadual tersebut, sebahagian besar daripada mereka adalah pegawai atasan dari Jabatan Mufti, iaitu 52.6 peratus. Manakala 31.6 peratus adalah responden dari Jabatan Agama Negeri dan 15.8 peratus daripada Jabatan Agama Persekutuan.

Jadual 2: Agamawan-Responden Kumpulan 1

\begin{tabular}{|l|c|}
\hline \multicolumn{1}{|c|}{ Jabatan } & $\begin{array}{c}\text { Bil. } \\
\text { Responden }\end{array}$ \\
\hline Jabatan Mufti Johor & 3 \\
\cline { 2 - 2 } Jabatan Mufti Perak & 2 \\
\cline { 2 - 2 } Jabatan Mufti Pahang & 2 \\
\cline { 2 - 2 } Jabatan Mufti Pulau Pinang & 3 \\
\cline { 2 - 2 } Jabatan Mufti Terengganu & 3 \\
\cline { 2 - 2 } Jabatan Mufti Negeri Sembilan & 2 \\
\cline { 2 - 2 } Jabatan Mufti Melaka & 2 \\
\cline { 2 - 2 } Jabatan Mufti Kelantan & 1 \\
\cline { 2 - 2 } Jabatan Mufti Selangor & 1 \\
\cline { 2 - 2 } Jabatan Mufti Sarawak & 1 \\
\hline Total & $20(52.6 \%)$ \\
\hline Jabatan Agama Islam Johor & $12(31.6 \%)$ \\
\hline Jabatan Kemajuan Islam Malaysia & $6(15.8 \%)$ \\
\hline JUMLAH KESELURUHAN & $38(100 \%)$ \\
\hline
\end{tabular}

Responden dari kumpulan 2 pula adalah seramai 40 orang daripada kalangan pensyarah Fakulti Pengajian Islam dari lima buah universiti tempatan, dua buah kolej dan sebuah Institut Pendidikan Guru. Jadual 3 menunjukkan latarbelakang 40 orang responden tersebut. Majoriti responden dalam kumpulan ini merupakan ahli akademik yang terdiri daripada pensyarah Fakulti Pengajian Islam dari Universiti Teknologi MARA yang membentuk 45 peratus daripada responden dalam kumpulan ini. Manakala 32.5 peratus pula terdiri daripada lain-lain universiti, 15 peratus diwakili oleh pensyarah dari kolej, dan hanya 7.5 peratus mewakili responden dari Institut Pendidikan Guru.

\footnotetext{
${ }^{1}$ Teknik Delphi direka untuk mengumpul pendapat dari sekumpulan pakar dalam bidang tertentu melalui kajian soal
} selidik yang dilakukan terhadap kumpulan yang sama melebihi satu pusingan. 
Jadual 3: Ahli akademik-Responden Kumpulan 2

\begin{tabular}{|l|r|r|}
\hline Badan Berkanun & \multicolumn{1}{|c|}{ Bil. } & \multicolumn{1}{|c|}{$\%$} \\
\hline Universiti Teknologi Malaysia (UTM) & 4 & 10.0 \\
Universiti Kebangsaan Malaysia (UKM) & 3 & 7.5 \\
Universiti Teknologi Mara (UiTM) & 18 & 45.0 \\
Universiti Tun Hussein Malaysia (UTHM) & 2 & 5.0 \\
Universiti Islam Antarabangsa (UIA) & 3 & 7.5 \\
Universiti Selangor (UNISEL) & 1 & 2.5 \\
Kolej Islam Melaka (KUIM) & 2 & 5.0 \\
Kolej Pengajian Islam Johor (MARSAH) & 4 & 10.0 \\
Institut Pendidikan Guru (IPG) & 3 & 7.5 \\
\hline JUMLAH KESELURUHAN & 40 & 100 \\
\hline
\end{tabular}

Responden dari kumpulan 3 pula adalah seramai 31 orang dan mereka adalah dalam kalangan perancang bandar yang terdiri daripada 18 pihak berkuasa tempatan dan dua orang responden dari Jabatan Perancang Bandar dan Desa (JPBD). Jadual 4 menunjukkan latarbelakang 31 orang responden tersebut. Berdasarkan jadual, majoriti responden dalam kumpulan ini terdiri dari Majlis Perbandaran Pulau Pinang. Mereka ini membentuk 12.9 peratus daripada responden dalam kumpulan ini. Manakala responden dari Majlis Bandaraya Shah Alam pula mewakili 9.67 peratus responden dan selebihnya terdiri daripada pihak berkuasa tempatan yang lain, termasuk responden dari Jabatan Perancang Bandar dan Desa.

Jadual 4: Perancang bandar-Responden Kumpulan 3

\begin{tabular}{|l|l|l|}
\hline Pihak Berkuasa Tempatan (PBT) & Bil. & $\%$ \\
\hline Majlis Bandaraya Johor Bahru (MBJB) & 2 & 6.45 \\
\hline Majlis Perbandaran Pasir Gudang (MPPG) & 2 & 6.45 \\
\hline Majlis Perbandaran Johor Bahru Tengah (MPJBT) & 2 & 6.45 \\
\hline Majlis Perbandaran Kulai (MPKu) & 1 & 3.23 \\
\hline Dewan Bandaraya Kuala Lumpur (DBKI) & 1 & 3.23 \\
\hline Majlis Perbandaran Kuantan (MPK) & 1 & 3.23 \\
\hline Majlis Perbandaran Alor Gajah (MPAG) & 1 & 3.23 \\
\hline Majlis Perbandaran Nilai (MPN) & 2 & 6.45 \\
\hline Majlis Perbandaran Taiping (MPTG) & 2 & 6.45 \\
\hline Majlis Perbandaran Manjung (MPM) & 1 & 3.23 \\
\hline Majlis Bandaraya Shah Alam (MBSA) & 3 & 9.67 \\
\hline Majlis Bandaraya Melaka Bersejarah (MBMB) & 1 & 3.23 \\
\hline Majlis Perbandaran Seberang Perai (MPSP) & 2 & 6.45 \\
\hline Majlis Perbandaran Pulau Pinang (MPPP) & 4 & 12.9 \\
\hline Majlis Perbandaran Ipoh (MPI) & 1 & 3.23 \\
\hline Majlis Perbandaran Temerloh (MPT) & 1 & 3.23 \\
\hline Majlis Perbandaran Kemaman (MPKemaman) & 1 & 3.23 \\
\hline Majlis Perbandaran Kajang (MPKJ) & 1 & 3.23 \\
\hline JPBD Johor & 1 & 3.23 \\
\hline JPBD Pulau Pinang & 1 & 3.23 \\
\hline JUMLAH KESELURUHAN & 31 & 100 \\
\hline
\end{tabular}

Sebagaimana perbincangan di atas, responden yang terlibat dalam kajian Delphi yang dijalankan adalah dalam kalangan cendekiawan Islam yang mempunyai pengetahuan dan pengalaman yang luas sama ada dalam bidang perancangan bandar dan/atau mempunyai latarbelakang pengajian Islam. Berbekalkan latar belakang yang dimiliki itu, melalui kajian Delphi pusingan pertama, responden diminta untuk membuat penentuan terhadap 72 indikator kesejahteraan yang telah dikenalpasti. Kepentingan 72 indikator itu adalah sebagai indikator kesejahteraan yang dinilai oleh responden melalui pusingan kedua kajian Delphi yang dijalankan. Bagi tujuan ini, tahap kepentingan 72 indikator yang dikenalpasti itu berdasarkan persepsi responden dengan menggunakan skala likert (1 hingga 5), nilai 1 mewakili tahap 
tidak penting dan nilai 5 mewakili tahap sangat penting. Nilai antara 1 hingga 5 mewakili tahap kepentingan antara tidak penting dan sangat penting. Selain itu, responden telah mengemukakan 40 senarai tambahan indikator kesejahteraan bandar bagi menentukan kepentingan 40 indikator tambahan. Maka, diadakan Delphi pusingan kedua dan terhasillah 112 indikator kesejahteraan bandar mengikut kepentingan sebagaimana dinilai oleh responden.

\subsection{HASIL KAJIAN DAN PERBINCANGAN}

Soal selidik yang telah diedarkan bertujuan mengenalpasti indikator yang boleh mengukur kesejahteraan dalam sesebuah kawasan perbandaran berasaskan perspektif Islam melalui enam aspek iaitu fizikal, akidah, akhlak, ekonomi, sosial, dan institusi. Analisis data soalselidik menggunakan Statical Package for Social Science (SPSS) 18.0 dan respon dibentangkan dalam peratus dan min seperti yang boleh dilihat dalam Jadual 5 hingga Jadual 10.

Hasil dapatan kajian indikator kesejahteraan bandar mengikut cendekiawan adalah seperti berikut: Aspek fizikal yang terdapat dalam Jadual 5 mendapat skor min tertinggi iaitu 4.0 ke atas adalah kewujudan persekitaran bersih 4.89, mempunyai bekalan air yang mencukupi 4.83, manakala indikator seterusnya iaitu wujudkan pusat kaunseling, wujudkan lebih banyak wakaf untuk dijadikan tempat berehat, terdapat hiasan air yang mengalir dan pengurusan sisa pepejal kepada tenaga boleh guna mendapat skor yang sama iaitu 4.82. Kemudahan sokongan di sekitar masjid seperti stesen minyak dan kedai-kedai kecil adalah 4.76. Indikator berikutnya iaitu kewujudan kemudahan awam atau infrastruktur asas yang lengkap dan berkualiti, mercu tanda menunjukkan arah kiblat, mengumpulkan seluruh komuniti dalam satu pusat kemudahan seperti hospital dan pejabat mendapat skor yang sama iaitu 4.75. Manakala, persekitaran aman daripada pencemaran udara, bunyi dan pencemaran air ialah 4.72. Terdapat dua indikator yang mempunyai skor min yang sama, 4.71, iaitu penyediaan tempat tidur musafir atau gelandangan dan pusat aktiviti untuk semua peringkat umur. Bagi kawasan lapang untuk solat Jumaat dan solat sunat seperti solat sunat aidilfitri mendapat skor min 4.67. Bagi indikator berikutnya, iaitu musolla di pejabat dan di kompleks membeli belah 4.66 dan masjid sebagai pusat khidmat masyarakat Islam dan bukan Islam 4.66. Indikator yang seterusnya iaitu wujudkan pusat jagaan haiwan yang berkeliaran seperti kucing, anjing dan lain-lain serta wujudkan zon makanan halal mempunyai skor yang sama iaitu 4.65. Bagi indikator wujudkan taman tema berkonsepkan Islam mendapat skor 4.63, medan hukuman hudud atau ta'zir 4.61, dan mewujudkan kaki lima berkeluasan 15 kaki untuk mengelakkan berselisih lelaki dan perempuan 4.59. Seterusnya, kewujudan kawasan pemeliharaan alam semulajadi 4.57 , tanah perkuburan sistematik dan tersusun mendapat skor 4.56, masjid berfungsi sebagai pusat pentadbiran bandar 4.55, dan masjid sebagai paksi pembinaan 4.48. Bangunan tersusun pula mendapat skor 4.42 dan kadar penggunaan pengangkutan awam yang tinggi 4.40. Banyak rumah ibadah untuk orang Islam didirikan 4.35. Kewujudan banyak kawasan lapang riadah 4.29 manakala penduduk berkembang dan bertambah 4.24. Diperbanyakkan syiar Islam seperti papan tanda al-Quran dan kata-kata nasihat 4.19 serta lanskap yang menarik 4.09. Bangunan mengarah kiblat 4.07. Banyak laluan basikal dan pejalan kaki yang diwujudkan 4.05. Kadar penggunaan basikal dan pejalan kaki yang tinggi 4.03. Terdapat lima aspek fizikal yang mendapat skor min yang sederhana iaitu 3.0 ke atas iaitu kewujudan pengasingan tempat ibadat berasaskan rumah kediaman penganut dan bangunan dengan senibina futuristik dan bercorak Islamik dengan skor 3.88. Manakala bangunan cantik dengan kepelbagaian bentuk dan warna mendapat skor 3.66. Kurang tempat ibadat agama lain 3.51 dan binaan bangunan rendah, tidak melebihi tiga tingkat mendapat skor 3.00. 
Jadual 5: Faktor Fizikal

\begin{tabular}{|c|c|c|c|c|c|c|c|}
\hline \multirow[t]{2}{*}{ Bil } & \multirow[t]{2}{*}{ Indikator } & \multicolumn{5}{|c|}{ Peratus } & \multirow[t]{2}{*}{ Min } \\
\hline & & $\begin{array}{l}\mathrm{TP} \\
(1)\end{array}$ & $\begin{array}{l}\mathrm{KP} \\
(2)\end{array}$ & $\begin{array}{l}\mathrm{N} \\
(3)\end{array}$ & $\begin{array}{c}P \\
(4)\end{array}$ & $\begin{array}{l}\text { SP } \\
(5)\end{array}$ & \\
\hline 1. & Bangunan mengarah kiblat & 1.7 & 1.7 & 10 & 10.4 & 21.6 & 4.07 \\
\hline 2. & Bangunan tersusun & 0.4 & 0.4 & 3.7 & 15.8 & 24.9 & 4.42 \\
\hline 3. & $\begin{array}{l}\text { Bangunan cantik dengan kepelbagaian bentuk dan } \\
\text { warna }\end{array}$ & 0.8 & 2.9 & 14.1 & 20.3 & 7.1 & 3.66 \\
\hline 4. & Kurang tempat ibadat agama lain & 2.1 & 4.6 & 17.4 & 10.4 & 10.8 & 3.51 \\
\hline 5. & $\begin{array}{l}\text { Kewujudan pengasingan tempat ibadat berasaskan } \\
\text { rumah kediaman penganut }\end{array}$ & 2.5 & 2.5 & 10.0 & 12.9 & 17.4 & 3.88 \\
\hline 6. & Kewujudan persekitaran bersih & - & 0.4 & 3.7 & 41.1 & 45.2 & 4.89 \\
\hline 7. & Binaan bangunan rendah, tidak melebihi 3 tingkat & 4.1 & 9.1 & 19.5 & 7.1 & 5.4 & 3.00 \\
\hline 8. & $\begin{array}{l}\text { Persekitaran aman daripada pencemaran udara, bunyi } \\
\text { dan pencemaran air }\end{array}$ & - & 0.4 & 11.6 & 33.2 & 45.2 & 4.72 \\
\hline 9. & Penduduk berkembang dan bertambah & - & 0.4 & 6.2 & 20.3 & 18.3 & 4.24 \\
\hline 10. & Banyak rumah ibadah untuk orang Islam & 0.4 & 0.8 & 4.6 & 15.8 & 23.7 & 4.35 \\
\hline 11. & Mempunyai bekalan air yang mencukupi & - & - & 0.4 & 6.6 & 38.2 & 4.83 \\
\hline 12. & Kadar penggunaan pengangkutan awam yang tinggi & - & - & 5.0 & 17 & 23.2 & 4.40 \\
\hline 13. & $\begin{array}{l}\text { Kadar penggunaan basikal dan pejalan kaki yang } \\
\text { tinggi }\end{array}$ & 0.4 & - & 11.2 & 19.5 & 14.1 & 4.03 \\
\hline 14. & $\begin{array}{l}\text { Banyak laluan basikal dan pejalan kaki yang } \\
\text { diwujudkan }\end{array}$ & - & 0.4 & 12.4 & 16.6 & 15.8 & 4.05 \\
\hline 15. & Kewujudan banyak kawasan lapang riadah & - & - & 5.4 & 21.2 & 18.7 & 4.29 \\
\hline 16. & Kewujudan kawasan pemeliharaan alam semulajadi & - & - & 1.7 & 15.8 & 27.8 & 4.57 \\
\hline 17. & $\begin{array}{l}\text { Kewujudan kemudahan awam/infrastruktur asas yang } \\
\text { lengkap dan berkualiti }\end{array}$ & - & - & 0.8 & 9.5 & 34.9 & 4.75 \\
\hline 18. & Masjid sebagai paksi pembinaan & - & - & 5.4 & 12.4 & 27.4 & 4.48 \\
\hline 19. & Masjid sebagai pusat pentadbiran bandar & - & - & 3.7 & 12.4 & 29.0 & 4.55 \\
\hline 20. & $\begin{array}{l}\text { Masjid sebagai pusat khidmat masyarakat Islam dan } \\
\text { bukan Islam }\end{array}$ & - & - & 0.8 & 12.4 & 32.0 & 4.66 \\
\hline 21. & $\begin{array}{l}\text { Kemudahan sokongan di sekitar masjid seperti stesen } \\
\text { minyak dan kedai-kedai kecil }\end{array}$ & - & - & - & 10.8 & 34.4 & 4.76 \\
\hline 22. & $\begin{array}{l}\text { Kawasan lapang untuk solat jumaat dan solat sunat } \\
\text { seperti solat sunat aidilfitri }\end{array}$ & - & - & 1.2 & 12.0 & 32.0 & 4.67 \\
\hline 23. & Mercu tanda menunjukkan arah kiblat & - & - & 0.4 & 10.4 & 34.4 & 4.75 \\
\hline 24. & $\begin{array}{l}\text { Musolla di pejabat dan di kompleks membeli } \\
\text { belah }\end{array}$ & - & - & 1.2 & 12.4 & 31.5 & 4.66 \\
\hline 25. & Wujudkan pusat kaunseling & - & - & 0.8 & 6.2 & 38.2 & 4.82 \\
\hline 26. & Penyediaan tempat tidur musafir atau gelandangan & - & - & 2.5 & 7.9 & 34.9 & 4.71 \\
\hline 27. & $\begin{array}{l}\text { Wujudkan pusat jagaan haiwan yang berkeliaran } \\
\text { seperti kucing, anjing dan lain-lain }\end{array}$ & - & - & 1.7 & 12.4 & 31.1 & 4.65 \\
\hline 28. & $\begin{array}{l}\text { Wujudkan lebih banyak wakaf untuk dijadikan tempat } \\
\text { berehat }\end{array}$ & - & - & 0.4 & 7.1 & 37.8 & 4.82 \\
\hline 29. & Pusat aktiviti untuk semua peringkat umur & - & - & 1.7 & 13.3 & 30.3 & 4.71 \\
\hline 30. & Wujudkan zon makanan halal & - & - & 0,8 & 9.5 & 34.9 & 4.65 \\
\hline 31. & Terdapat hiasan air yang mengalir & - & - & 0.8 & 16.6 & 27.8 & 4.82 \\
\hline 32. & Wujudkan taman tema berkonsepkan Islam & - & - & 1.2 & 17.0 & 27.0 & 4.63 \\
\hline 33. & $\begin{array}{l}\text { Mengumpulkan seluruh komuniti dalam satu pusat } \\
\text { kemudahan seperti hospital, pejabat }\end{array}$ & - & - & 0.4 & 8.3 & 36.5 & 4.75 \\
\hline 34. & $\begin{array}{l}\text { Mewujudkan kaki lima berkeluasan } 15 \text { kaki untuk } \\
\text { mengelakkan berselisih lelaki perempuan }\end{array}$ & - & - & - & 6.6 & 38.6 & 4.59 \\
\hline 35. & Tanah perkuburan sistematik dan tersusun & - & 0.4 & 2.1 & 14.1 & 28.6 & 4.56 \\
\hline 36. & Lanskap yang menarik & - & 0.4 & 10.8 & 18.3 & 15.8 & 4.09 \\
\hline 37. & Diperbanyakkan syiar Islam seperti papan tanda al- & 0.4 & - & 8.7 & 17.4 & 18.7 & 4.19 \\
\hline
\end{tabular}


Norizam Lagiman et al. / UMRAN - International Journal of Islamic and Civilizational Studies. vol.2. no.3 (2015) 10-24

\begin{tabular}{|l|l|c|c|c|c|c|c|}
\hline & quran dan kata-kata nasihat & & & & & & \\
\hline 38. & $\begin{array}{l}\text { Bangunan dengan senibina futuristik dan bercorak } \\
\text { Islamik }\end{array}$ & - & 2.1 & 12.9 & 18.3 & 12.0 & 3.88 \\
\hline 39. & Medan hukuman hudud atau ta'zir & - & - & 2.1 & 13.3 & 29.9 & 4.61 \\
\hline $\mathbf{4 0 .}$ & Pengurusan sisa pepejal kepada tenaga boleh guna & - & - & - & 7.9 & 37.3 & 4.82 \\
\hline
\end{tabular}

Sumber: Soal selidik 2014

Faktor akidah yang terdapat dalam Jadual 6 mendapati bahawa faktor yang mendominasi kesejahteraan sesebuah bandar dengan mendapat skor min yang tinggi iaitu 4.0 ke atas adalah penduduk membaca al-Quran sebagai amalan harian 4.90. Indikator melahirkan golongan kader Islam yang terbaik hingga mampu memimpin dunia 4.86. Bagi nisbah penduduk Islam tinggi memperoleh skor 4.73, mengambil kira pandangan ilmuan Islam dan kelestariannya mendapat skor 4.60, manakala tahap keimanan penduduk tinggi (diukur melalui amalan wajib dan sunat) mendapat skor 4.56. Perlaksanaan syariah Islam dalam masyarakat 4.54, kewujudan golongan cerdik pandai agama dalam masyarakat 4.50 dan penduduk mengutamakan solat berjemaah 4.43.

Aspek akidah yang asas adalah memahami agama dengan memahami asas-asas dan Tasawwur Islam. Seseorang yang mempunyai akidah yang mantap akan menjadi kuat pegangan agamanya. Beliau akan menjadi manusia yang soleh walau di mana dan dalam keadaan apa sekalipun dia berada. Taufiq Wa'iy (2004) menjelaskan "pada hakikatnya tidak ada satupun kekuatan yang dapat menandingi kekuatan iman yang berfungsi mengarah dan menentukan tindakan-tindakan manusia. Akidah akan membantu individu memandang apa yang diinginkan dan memberi semangat untuk mencapainya", manakala Hasan Hudaibi (1977) menyebutkan "dirikanlah Islam di dalam hati-hati kamu nescaya akan tertegak Islam di atas muka bumi kamu".

\section{Jadual 6: Faktor Akidah}

\begin{tabular}{|l|l|c|c|c|c|c|c|}
\hline \multirow{2}{*}{ Bil } & \multicolumn{1}{|c|}{ Indikator } & \multicolumn{3}{|c|}{ Peratus } & \multirow{2}{*}{ Min } \\
\cline { 3 - 6 } & & $\begin{array}{c}\text { TP } \\
(1)\end{array}$ & $\begin{array}{c}\text { KP } \\
(2)\end{array}$ & $\begin{array}{c}\text { N } \\
(3)\end{array}$ & $\begin{array}{c}\text { P } \\
(4)\end{array}$ & $\begin{array}{c}\text { SP } \\
(5)\end{array}$ & \\
\hline 1. & Nisbah penduduk Islam tinggi & - & - & - & 12.0 & 33.2 & 4.73 \\
\hline 2. & $\begin{array}{l}\text { Tahap keimanan penduduk tinggi (diukur melalui } \\
\text { amalan wajib dan sunat) }\end{array}$ & - & - & 1.2 & 17.0 & 27.0 & 4.56 \\
\hline 3. & Penduduk membaca al-Quran sebagai amalan harian & - & - & - & 4.1 & 41.1 & 4.90 \\
\hline 4. & $\begin{array}{l}\text { Penduduk melaksanakan tuntutan rukun Islam secara } \\
\text { berterusan }\end{array}$ & 0.4 & - & 3.7 & 14.1 & 29.0 & 4.58 \\
\hline 5. & Perlaksanaan syariah Islam dalam masyarakat & - & - & 2.1 & 16.6 & 26.6 & 4.54 \\
\hline 6. & Penduduk mengutamakan solat berjemaah & - & - & 5.0 & 15.8 & 24.5 & 4.43 \\
\hline 7. & $\begin{array}{l}\text { Kewujudan golongan cerdik pandai agama dalam } \\
\text { masyarakat }\end{array}$ & - & - & 2.9 & 16.6 & 25.7 & 4.50 \\
\hline 8. & $\begin{array}{l}\text { Mengambil kira pandangan ilmuan Islam dan } \\
\text { kelestariannya }\end{array}$ & - & - & 2.1 & 13.7 & 29.5 & 4.60 \\
\hline 9. & $\begin{array}{l}\text { Melahirkan golongan kader Islam yang terbaik hingga } \\
\text { mampu memimpin dunia }\end{array}$ & - & - & 0.4 & 5.4 & 39.4 & 4.86 \\
\hline
\end{tabular}

Sumber: Soal selidik 2014

Analisis terhadap aspek akhlak yang diperoleh dari Jadual 7, mendapati skor min tertinggi adalah hubungan yang baik sesama manusia 4.86 manakala anggota masyarakat mempunyai ilmu pengetahuan dan membimbing masyarakat 4.84, dan qiamullail (berjaga malam) untuk ibadah mendapat skor 4.83. Bagi mengutamakan amanah dalam kehidupan 4.80, indikator mengutamakan kepentingan masyarakat berbanding kepentingan individu dan budaya guna semula (recycle) barangan mendapat skor min 4.79. Bagi indikator menghormati ibu bapa, para ilmuan dan orang yang lebih tua 4.78. Indikator yang menyatakan penglibatan dalam aktiviti kemasyarakatan, kebudayaan Islam seperti berzanji, nasyid, marhaban mengikut masa yang sesuai dan menghidupkan majlis ilmu mendapat skor min yang sama iaitu 4.76. Indikator aurat sentiasa dijaga 4.75 dan mengutamakan amalan sunnah dalam kehidupan 4.72. Bagi indikator seterusnya iaitu sabar dalam menghadapi ujian dan kadar celik al-Quran mendapat skor min 
4.71. Di samping itu, penduduk mengamalkan uzlah (bertafakur) 4.69, penduduk menyempurnakan janji 4.68, mewujudkan program dan aktiviti khusus melatih remaja berasaskan islam 4.6, penduduknya menguruskan masa dengan betul 4.60, penduduk kurang bercakap perkara sia-sia 4.57, banyak berlapar (puasa) 4.51 dan akhirnya bagi indikator mempunyai pelan strategik dalam ilmu dakwah Muslim dan non-Muslim mendapat skor min 4.49.

Jadual 7: Faktor Akhlak

\begin{tabular}{|c|c|c|c|c|c|c|c|}
\hline \multirow[t]{2}{*}{ Bil } & \multirow{2}{*}{ Indikator } & \multicolumn{5}{|c|}{ Peratus } & \multirow{2}{*}{ Min } \\
\hline & & $\begin{array}{l}\mathrm{TP} \\
\text { (1) }\end{array}$ & $\begin{array}{l}\text { KP } \\
\text { (2) }\end{array}$ & $\begin{array}{c}\mathrm{N} \\
(3)\end{array}$ & $\begin{array}{c}\mathrm{P} \\
(4)\end{array}$ & $\begin{array}{l}\text { SP } \\
(5)\end{array}$ & \\
\hline 1. & Hubungan yang baik sesama manusia & - & - & 0.8 & 4.6 & 39.8 & 4.86 \\
\hline 2. & Penduduk menyempurnakan janji & - & - & 1.7 & 10.8 & 32.8 & 4.68 \\
\hline 3. & Sabar dalam menghadapi ujian & - & - & 1.7 & 9.5 & 34.0 & 4.71 \\
\hline 4. & Aurat sentiasa dijaga & - & - & 1.2 & 8.7 & 35.3 & 4.75 \\
\hline 5. & Penglibatan dalam aktiviti masyarakat & - & - & 0.8 & 9.1 & 35.3 & 4.76 \\
\hline 6. & Kadar celik al-Quran & - & - & 0.4 & 12.0 & 32.8 & 4.71 \\
\hline 7. & $\begin{array}{l}\text { Mengutamakan kepentingan masyarakat berbanding } \\
\text { kepentingan individu }\end{array}$ & - & - & 0.8 & 7.5 & 36.9 & 4.79 \\
\hline 8. & Mengutamakan amalan sunnah dalam kehidupan & - & - & 1.2 & 10.0 & 34.0 & 4.72 \\
\hline 9. & $\begin{array}{l}\text { Menghormati ibu bapa, para ilmuan dan orang yang } \\
\text { lebih tua }\end{array}$ & - & - & 0.4 & 8.7 & 36.1 & 4.78 \\
\hline 10. & Mengutamakan amanah dalam kehidupan & - & - & 0.4 & 7.9 & 36.9 & 4.80 \\
\hline 11. & Penduduk kurang bercakap perkara sia-sia & - & - & 2.1 & 14.9 & 28.2 & 4.57 \\
\hline 12. & Banyak berlapar (puasa) & - & - & 1.7 & 18.7 & 24.9 & 4.51 \\
\hline 13. & Qiamullail (berjaga malam untuk ibadah) & - & - & 0.8 & 6.2 & 37.8 & 4.83 \\
\hline 14. & Penduduk mengamalkan uzlah (bertafakur) & - & - & 0.8 & 12.0 & 32.4 & 4.69 \\
\hline 15. & Penduduknya menguruskan masa dengan betul & - & - & 1.2 & 15.4 & 28.6 & 4.60 \\
\hline 16. & $\begin{array}{l}\text { Kebudayaan Islam seperti berzanji, nasyid, marhaban } \\
\text { mengikut masa yang sesuai }\end{array}$ & - & - & - & 10.8 & 34.4 & 4.76 \\
\hline 17. & Budaya guna semula (recycle) barangan & - & - & 0.4 & 8.3 & 36.5 & 4.79 \\
\hline 18. & Menghidupkan majlis ilmu & - & - & 0.8 & 9.1 & 35.3 & 4.76 \\
\hline 19. & $\begin{array}{l}\text { Mewujudkan program dan aktiviti khusus melatih } \\
\text { remaja berasaskan islam }\end{array}$ & - & - & 0.8 & 13.3 & 31.1 & 4.66 \\
\hline 20. & $\begin{array}{l}\text { Anggota masyarakat mempunyai ilmu pengetahuan } \\
\text { dan membimbing masyarakat }\end{array}$ & - & - & & 7.1 & 38.2 & 4.84 \\
\hline 21. & $\begin{array}{l}\text { Mempunyai pelan strategik dalam ilmu dakwah } \\
\text { Muslim dan non-Muslim }\end{array}$ & - & - & 2.5 & $\begin{array}{l}17.8 \\
\end{array}$ & 24.9 & 4.49 \\
\hline
\end{tabular}

Sumber: Soal selidik 2014

Analisis terhadap aspek ekonomi yang diperoleh dari Jadual 8 mendapati, skor min tertinggi adalah berkembang budaya waqaf dalam kalangan penduduk dengan mendapat skor 4.91, dan penduduk tidak mengamalkan atau menggunakan sistem kewangan berasaskan riba 4.75. Bagi indikator kedapatan makanan halal dan baik secara meluas 4.68, muamalat dalam urusan jual beli 4.57 , dan penduduk Islam mengeluarkan zakat 4.47. Manakala, sistem wakaf, zakat dan baitulmal tersusun, kemas dan sistematik 4.42, rasuah dibanteras mendapat skor 4.39, dan tiada kegiatan bercanggah seperti penjualan arak, judi, pelacuran dan rumah urut 4.31. Untuk indikator banyak punca rezeki/peluang pekerjaan 4.12, peniaga tidak menipu dalam timbangan dan semuanya hidup harmoni pula mendapat skor 4.07, dan kewujudan budaya menabung wang skornya ialah 3.90. Bagi budaya bersedekah berkembang dalam masyarakat 3.63, kurang bebanan hutang 3.45, dan akhirnya indikator berhemah dalam berbelanja atau memanfaatkan rezeki mendapat skor min 3.03. 
Jadual 8: Faktor Ekonomi

\begin{tabular}{|c|c|c|c|c|c|c|c|}
\hline \multirow[t]{2}{*}{ Bil } & \multirow[t]{2}{*}{ Indikator } & \multicolumn{5}{|c|}{ Peratus } & \multirow[t]{2}{*}{ Min } \\
\hline & & $\begin{array}{l}\mathrm{TP} \\
(1)\end{array}$ & $\begin{array}{l}\text { KP } \\
(2)\end{array}$ & $\begin{array}{l}\mathrm{N} \\
(3)\end{array}$ & $\begin{array}{l}P \\
(4)\end{array}$ & $\begin{array}{l}\text { SP } \\
(5)\end{array}$ & \\
\hline 1. & Kedapatan makanan halal dan baik secara meluas & - & - & 0.8 & 12.4 & 32.0 & 4.68 \\
\hline 2. & Muamalat dalam urusan jual beli & - & - & 1.2 & 16.6 & 27.4 & 4.57 \\
\hline 3. & Banyak punca rezeki/peluang pekerjaan & 1.7 & 1.7 & 8.7 & 10.4 & 22.8 & 4.12 \\
\hline 4. & Penduduk Islam mengeluarkan zakat & - & 0.4 & 2.9 & 16.6 & 25.3 & 4.47 \\
\hline 5. & $\begin{array}{l}\text { Budaya bersedekah berkembang dalam } \\
\text { masyarakat }\end{array}$ & 0.8 & 3.3 & 14.1 & 20.3 & 6.6 & 3.63 \\
\hline 6. & Kurang bebanan hutang & 2.9 & 5.4 & 15.4 & 11.2 & 10.4 & 3.45 \\
\hline 7. & Kewujudan budaya menabung wang & 2.5 & 2.9 & 9.1 & 12.4 & 18.3 & 3.90 \\
\hline 8. & Berkembang budaya waqaf dikalangan penduduk & - & - & 0.4 & 2.9 & 41.9 & 4.91 \\
\hline 9. & Berhemah dalam berbelanja/ Manfaatkan rezeki & 3.3 & 10.8 & 17.8 & 7.5 & 5.8 & 3.03 \\
\hline 10. & Penduduk tidak menggunakan sistem kewangan riba & - & - & 0.4 & 10.4 & 34.4 & 4.75 \\
\hline 11. & $\begin{array}{l}\text { Tiada kegiatan bercanggah seperti penjualan arak, } \\
\text { judi, pelacuran dan rumah urut }\end{array}$ & - & 0.4 & 5.0 & 19.9 & 19.9 & 4.31 \\
\hline 12. & Rasuah dibanteras & 0.8 & 0.4 & 4.6 & 13.7 & 25.7 & 4.39 \\
\hline 13. & Peniaga tidak menipu dalam timbangan & 1.7 & 1.7 & 10.0 & 10.4 & 21.6 & 4.07 \\
\hline 14. & $\begin{array}{l}\text { Sistem wakaf, zakat dan baitulmal tersusun kemas / } \\
\text { sistematik }\end{array}$ & 0.4 & 0.4 & 3.7 & 15.8 & 24.9 & 4.42 \\
\hline
\end{tabular}

Sumber: Soal selidik 2014

Analisis terhadap aspek sosial yang diperoleh dari Jadual 9 mendapati, skor min tertinggi yang menyumbang kepada kesejahteraan sesebuah bandar adalah pengamalan adab dalam institusi kekeluargaan 4.89. Manakala perkembangan budaya ilmu 4.83, kawalan pendatang dan penduduk asing bagi mengawal gejala sosial 4.76, kesatuan umat Islam 4.72, dan hiburan disekat 4.57. Seterusnya, hikmah dalam setiap tindakan (ada perancangan/perbincangan) 4.41, pengurangan kadar jenayah 4.36, dan menganjurkan sukan bertaraf dunia berkonsepkan syariah mendapat skor min 4.30. Bagi indikator penduduk bertanggungjawab menjaga keselamatan dan keharmonian masyarakat 4.25, pengawalan pergaulan bebas dan maksiat di bandar 4.06, manakala indikator penglibatan penduduk dalam badan kebajikan, dakwah Islamiah 4.03. Terdapat empat aspek sosial mendapat skor min 3.0 ke atas (sederhana) iaitu hormat menghormati hak orang lain 3.88, saling membantu dikalangan penduduk 3.66, keadilan dalam semua urusan (tiada penganiyaan atau kezaliman) 3.49 dan indikator aktiviti dakwah berkembang mendapat skor min 3.00 .

Analisis terhadap aspek institusi yang diperoleh dari Jadual 10 mendapati, skor min tertinggi adalah kewujudan pelbagai institusi sukarelawan seperti askar, polis, rela, rukun tetangga secara sukarela 4.81. Manakala indikator seterusnya yang mendapat skor min yang tinggi adalah mewujudkan satu badan yang berfungsi mengajak ma'ruf dan mencegah kemungkaran serta mewujudkan institusi falak syari'e dengan min 4.80. Terdapat juga indikator yang mendapat skor min yang sama, iaitu 4.76 iaitu bagi indikator kewujudan institusi penjagaan dan pembelaan terhadap anak-anak yatim, fakir miskin, ibu tunggal dan warga emas yang tinggi dan pengurusan hal ehwal agama secara sistematik bertepatan hukum syara'. Pengurusan dan pentadbiran dalam Islam mempunyai kaitan secara langsung dengan keimanan kepada Allah S.W.T. iaitu pendekatan yang diambil dengan menggunakan pendekatan tauhid bagi menentukan segala tindakan pengurusan adalah untuk menyempurnakan maslahah kebaikan yang ditentukan oleh syariat. Pertama, untuk menyempurnakan amanah yang diterima manusia daripada Allah S.W.T. sebagai hamba dan khalifah-Nya di muka Bumi. Kedua, untuk mengerjakan amal soleh secara syura dalam organisasi. Ketiga, untuk membina peradaban yang diredhai Allah berlandaskan ajaran Tauhid. Keempat bertanggungjawab menghapus fasad (keburukan) untuk menegakkan keadilan dalam organisasi dan juga dalam masyarakat. Kelima, matlamat akhir pengurusan dan pentadbiran ialah mencapai al-falah iaitu kesejahteraan dan keberuntungan serta kemenangan di dunia dan akhirat (Mohd Affandi Hassan,1990). 
Jadual 9: Faktor Sosial

\begin{tabular}{|c|c|c|c|c|c|c|c|}
\hline \multirow[t]{2}{*}{ Bil } & \multirow{2}{*}{ Indikator } & \multicolumn{5}{|c|}{ Peratus } & \multirow[t]{2}{*}{ Min } \\
\hline & & $\begin{array}{l}\text { TP } \\
(1)\end{array}$ & $\begin{array}{l}\text { KP } \\
(2)\end{array}$ & $\begin{array}{c}\mathrm{N} \\
(3)\end{array}$ & $\begin{array}{l}P \\
(4)\end{array}$ & $\begin{array}{l}\text { SP } \\
(5)\end{array}$ & \\
\hline 1. & Saling membantu dalam kalangan penduduk & 0.8 & 2.9 & 14.1 & 20.3 & 7.1 & 3.66 \\
\hline 2. & $\begin{array}{l}\text { Keadilan dalam semua urusan (tiada penganiyaan / } \\
\text { kezaliman) }\end{array}$ & 2.1 & 4.6 & 17.8 & 10.4 & 10.4 & 3.49 \\
\hline 3. & Hormat menghormati hak orang lain & 2.5 & 2.5 & 10.0 & 12.9 & 17.9 & 3.88 \\
\hline 4. & Pengamalan adab dalam institusi kekeluargaan & - & - & 0.4 & 3.7 & 41.1 & 4.89 \\
\hline 5. & Aktiviti dakwah berkembang & 4.1 & 9.1 & 19.5 & 7.1 & 5.4 & 3.00 \\
\hline 6. & Kesatuan umat Islam & - & - & 0.4 & 11.6 & 33.2 & 4.72 \\
\hline 7. & $\begin{array}{l}\text { Penduduk bertanggungjawab menjaga keselamatan } \\
\text { dan keharmonian masyarakat }\end{array}$ & - & 0.4 & 6.2 & 19.9 & 18.7 & 4.25 \\
\hline 8. & Pengurangan kadar jenayah & 0.4 & 0.8 & 4.6 & 15.4 & 24.1 & 4.36 \\
\hline 9. & Perkembangan budaya ilmu & - & - & 0.4 & 6.6 & 38.2 & 4.83 \\
\hline 10. & $\begin{array}{l}\text { Hikmah dalam setiap tindakan (ada } \\
\text { perancangan/perbincangan) }\end{array}$ & - & - & 5.0 & 16.6 & 23.7 & 4.41 \\
\hline 11. & $\begin{array}{l}\text { Penglibatan penduduk dalam badan kebajikan, dakwah } \\
\text { Islamiah }\end{array}$ & 0.4 & - & 11.2 & 19.5 & 14.1 & 4.03 \\
\hline 12. & Pengawalan pergaulan bebas dan maksiat di bandar & - & 0.4 & 12.0 & 17.0 & 15.8 & 4.06 \\
\hline 13. & $\begin{array}{l}\text { Menganjurkan sukan bertaraf dunia berkonsepkan } \\
\text { syariah }\end{array}$ & - & - & 5.4 & 20.7 & 19.1 & 4.30 \\
\hline 14. & Hiburan disekat & - & - & 1.7 & 15.8 & 27.8 & 4.57 \\
\hline 15. & $\begin{array}{l}\text { Kawalan pendatang dan penduduk asing bagi } \\
\text { mengawal gejala sosial }\end{array}$ & - & - & 0.8 & 9.1 & 35.3 & 4.76 \\
\hline
\end{tabular}

Sumber: Soal selidik 2014)

Indikator seterusnya iaitu kewujudan institusi perbankan Islam memperoleh skor min 4.70. Indikator berikutnya iaitu kewujudan penguatkuasaan undang-undang syariat Islam dan masjid sentiasa dimakmurkan mendapat skor min 4.67. Mustafa al-Siba'i (1984) menyatakan bahawa masjid telah diberikan kedudukan yang tinggi dalam ajaran Islam dengan kelebihannya sebagai tempat ibadat bagi umat Islam dan peranannya sebagai pusat aktiviti masyarakat dan negara. Menurut Salih Ghanim alSadlan (1994), Rasulullah S.A.W. telah mengambil langkah membina masjid setiap kali baginda sampai di tempat baru. Menurut Yusof al-Qaradhawi (1970), umat Islam berjaya mencapai kejayaan melalui aktiviti pengimarahan masjid yang begitu hebat dalam sejarah Islam, kerana masjid adalah medium utama kepada Islam itu sendiri dari segi keagamaan, politik dan kemasyarakatan. Seterusnya, bagi indikator kewujudan institusi pendidikan agama Islam dalam masyarakat mendapat skor min 4.66, manakala kewujudan institusi kepimpinan dan pengurusan bandar yang cemerlang 4.64. Untuk indikator mewujudkan sistem pendidikan berintegrasi tahfiz dan akademik seperti sekolah ulul albab bagi melahirkan insan quranik, ensklopedik dan ijtihadik memperolehi skor min 4.63. Indikator kewujudan institusi dakwah dan kebajikan dalam masyarakat 4.55, dan akhirnya kebertanggungjawaban atau kepatuhan terhadap institusi keluarga Islam (penyelesaian permasalahan keluarga mengikut aturan Islam) mendapat skor min 4.48 .

Jadual 10: Faktor Institusi

\begin{tabular}{|c|l|c|c|c|c|c|c|}
\hline Bil & \multicolumn{1}{|c|}{ Indikator } & \multicolumn{4}{|c|}{ Peratus } & \multicolumn{1}{c|}{ Min } \\
\cline { 3 - 7 } & & $\begin{array}{c}\text { TP } \\
(1)\end{array}$ & $\begin{array}{c}\text { KP } \\
(2)\end{array}$ & $\begin{array}{c}\text { N } \\
(3)\end{array}$ & $\begin{array}{c}\text { P } \\
(4)\end{array}$ & $\begin{array}{c}\text { SP } \\
(5)\end{array}$ & \\
\hline 1 & $\begin{array}{l}\text { Kebertanggungjawaban/kepatuhan } \\
\text { terhadap institusi keluarga Islam (penyelesaian } \\
\text { permasalahan keluarga mengikut aturan Islam) }\end{array}$ & - & - & 5.4 & 12.4 & 27.4 & 4.48 \\
\hline 2 & $\begin{array}{l}\text { Kewujudan institusi dakwah dan kebajikan dalam } \\
\text { masyarakat }\end{array}$ & - & - & 3.7 & 12.9 & 28.6 & 4.55 \\
\hline 3 & $\begin{array}{l}\text { Kewujudan penguatkuasaan undang-undang syariat } \\
\text { Islam }\end{array}$ & - & - & 0.8 & 12.9 & 31.5 & 4.67 \\
\hline
\end{tabular}




\begin{tabular}{|c|c|c|c|c|c|c|c|}
\hline 4 & $\begin{array}{l}\text { Pengurusan Hal Ehwal Agama secara sistematik } \\
\text { bertepatan hukum syara' }\end{array}$ & - & - & - & 10.8 & 34.4 & 4.76 \\
\hline 5 & $\begin{array}{l}\text { Kewujudan institusi pendidikan agama Islam dalam } \\
\text { masyarakat }\end{array}$ & - & - & 1.2 & 12.4 & 31.5 & 4.66 \\
\hline 6 & $\begin{array}{l}\text { Kewujudan institusi penjagaan dan pembelaan } \\
\text { terhadap anak-anak yatim, fakir miskin, ibu tunggal } \\
\text { dan warga } \\
\text { emas yang tinggi }\end{array}$ & - & - & 0.4 & 10.0 & 34.9 & 4.76 \\
\hline 7 & Masjid sentiasa dimakmurkan & - & - & 1.2 & 12.0 & 32.0 & 4.67 \\
\hline 8 & $\begin{array}{l}\text { Kewujudan pelbagai institusi sukarelawan seperti } \\
\text { askar, polis, rela, rukun tetangga secara sukarela }\end{array}$ & - & - & 0.8 & 6.6 & 37.8 & 4.81 \\
\hline 9 & Kewujudan institusi perbankan Islam & - & - & 2.5 & 8.3 & 34.4 & 4.70 \\
\hline 10 & $\begin{array}{l}\text { Kewujudan institusi kepimpinan dan pengurusan } \\
\text { bandar cemerlang }\end{array}$ & - & - & 1.7 & 12.9 & 30.7 & 4.64 \\
\hline 11 & $\begin{array}{l}\text { Mewujudkan satu badan yang berfungsi mengajak } \\
\text { ma'ruf dan mencegah kemungkaran }\end{array}$ & - & - & 0.8 & 7.1 & 37.3 & 4.80 \\
\hline 12 & $\begin{array}{l}\text { Mewujudkan sistem pendidikan berintegrasi tahfiz dan } \\
\text { akademik seperti sekolah ulul albab bagai melahirkan } \\
\text { insan quranik, ensklopedik dan ijtihadik }\end{array}$ & - & - & 1.7 & 13.3 & 30.3 & 4.63 \\
\hline 13 & Mewujudkan institusi falak syari'e & - & - & 0.8 & 7.1 & 37.3 & 4.80 \\
\hline
\end{tabular}

Sumber: Soal selidik 2014

\subsection{KESIMPULAN}

Masyarakat bandar adalah masyarakat yang bertamadun dalam corak kehidupan sosial, ekonomi dan politik. Ciri-ciri masyarakat bertamadun ialah mempunyai adab, berilmu pengetahuan, berpandangan luas, berpandangan jauh dan tersusun serta terdiri daripada masyarakat yang penuh dengan nilai keinsanan. Bandar bukanlah sumber atau pusat berlakunya maksiat dan munculnya gejala-gejala negatif tetapi watak-watak manusia yang menghuni bandar tersebut menyebabkan kerosakan dalam kesejahteraan sesebuah bandar. Oleh yang demikian itu, penilaian konsep dan falsafah bandar yang ada di negara ini khususnya dan negara-negara Islam umumnya perlu di lakukan atau dinilai kembali supaya bandar-bandar di negara ini menjadi paksi dan pusat kepada pembinaan tamadun umat dan penyubur kerjasama dalam kalangan masyarakat bandar. Hasil kajian ini dapat dijadikan panduan dalam merancang bandar yang sejahtera dengan memperbaiki bandar yang sedia ada dan dapat dijadikan asas penting dalam merancang perancangan bandar pada masa akan datang.

Berasaskan tinjauan terhadap konsep indikator, contoh indikator bandar lestari dan literatur mengenai ciri-ciri bandar Islam, dapat disimpulkan bahawa indikator kesejahteraan bandar Islam perlu dibangunkan kerana sehingga kini belum wujud indikator kesejahteraan bandar dari perspektif Islam. Indikator pembangunan sedia ada di peringkat bandar adalah lebih berbentuk pembangunan material termasuk yang merangkumi dimensi secara menyeluruh (sosio, ekonomi dan fizikal) seperti indikator bandar lestari di luar negara dan MURNINET di Malaysia. Berasaskan penelitian terhadap ciri-ciri bandar Islam terdapat dimensi bukan material yang penting diambil kira dalam mengukur kesejahteraan sesebuah bandar termasuk aspek akidah, penghayatan terhadap akhlak dan syariat Islam boleh dijadikan panduan untuk membina indikator kesejahteraan.

Dalam Islam, kesejahteraan bandar perlu berasaskan matlamat hidup Islam iaitu al-falah. Prinsip al-falah merangkumi pelbagai dimensi hidup termasuk dimensi aqidah, akhlak, sosial, ekonomi dan institusi yang dibentuk berasaskan perintah, larangan, pengajaran dan petunjuk dalam al-Quran dan alSunnah. Dalam membina indikator kesejahteraan bandar dari perspektif Islam, kajian ini mengambil pendekatan dengan merujuk al-Quran dan al-Sunnah sebagai sumber asas dan kajian serta pandangan cendekiawan sebagai sumber kedua. Oleh kerana usaha untuk mengeluarkan indikator merupakan suatu yang besar dan mencabar dan di luar kemampuan untuk seseorang individu, maka kajian ini merujuk 
kepada pakar bidang terdiri daripada cendekiawan pengajian Islam dan perancang bandar untuk menyaring dan menilai indikator seterusnya memilih indikator yang sesuai dengan perspektif Islam. Adalah diharapkan pendekatan ini akan membawa kepada ijtihad yang menepati atau hampir kepada pendekatan dari perspektif Islam dan menghasilkan indikator yang lebih baik berbanding dengan indikator sedia ada yang berteraskan falsafah Barat.

\section{Rujukan}

Al-Quran al-Karim.

Abd al-Rahman bin Khaldun. (1993). Muqaddimah Ibn Khaldun. Al-Tab`ah al-'Ula. Beirut: Dar alKutub.

Ahmad Hezri Adnan. (2002). Sustainable Development Indicator for the State of Selangor. Latihan Ilmiah. Bangi: Universiti Kebangsaan Malaysia.

Ahmad Zaki Abdul Latiff. (1997). Perbandaran di Timur Tengah: Kesannya Terhadap Masyarakat Islam abad 1-111 Hijrah. Kuala Lumpur: Dewan Bahasa dan Pustaka.

Mohd. Affandi Hassan. (1992). The Tawhidic Approach in Management and Public Administration Concepts, Principles and An Alternative Model. Kuala Lumpur: National Institute of Public Administration Malaysia.

Mohamad Tajuddin Mohd Rasdi dan Roslan Abdul Manan. (2001). Konsep Perbandaran Islam: Suatu Gagasan Alternatif. Skudai: Penerbit Universiti Teknologi Malaysia.

Mustafa al-Siba'i. (1984). Al-Sirah al-Nabawiyyah: Durus wa Ibar. Jordan: Al-Maktab al-Islami. h.7475.

Paola Jirón \& Giulietta Fadda. (1999). The Process of Formulating Quality of Life Indicators Using a Gender Perspective. The Need for "Gendered" Indicators in Urban Policy, Programme and Project Analysis. Diakses melalui http://www.calidaddevida.uchile.cl/pdf/Process.pdf. Tarikh akses: 6 November 2010.

Salih Ghanim al-Sadlan. (1994). Al-Masjid wa Dauruhu fi al-Tarbiyyah wa al-taujih. Riyadh: Dar Balansiyah, h.17-18.

Taufik Yusof Al-Wa'iy. (2004). Al Iman Waiqadhu al-Quwaa al-Khafiah (Iman Membangkitkan Kekuatan). Vol 15. Kuwait: Yusuf Publication, Darul Buhus Al-Ilmiah.

Ting Chew Peh. (1993). Konsep Asas Sosiologi. Kuala Lumpur: Dewan Bahasa dan Pustaka.

Yusof al-Qaradhawi. (1970). Al-Ibadah fial-Islam. Beirut: Muassasah al-Risalah, h.233 